ACTA VET. BRNO, 58, 1509: 353-362

\title{
INFLUENCE OF SUBINHIBITORY AND INHIBITORY CONCENTRATIONS OF ANTIMICROBIAL AGENTS ON THE CHEMILUMINESCENCE OF PHAGOCYTOSING GRANULOCYTES
}

\author{
Danida SOLTISOVÅ and J. LOKA * \\ Institute of Biophysics, Czechoslovak Academy of Sciences, 61265 Bmo, Dept. Clin. Immunolozy, \\ Medical Faculty Hospital, 65691 Brno
}

Recetved March 14, 1989

Abstract

S o $1 \mathrm{t}$ i s o vá D a n i e la, J. L o k a j. : Infuence of Subinhibitory and Inhibitory Concentrations of Antimicrobial Agents on the Chemiluminiscence of Phagocytosing Granulocytes. Acta vet. Bmo, 58, 1989: 353-362.

This study was aimed at determining the effect of commonly administered antibacterial drugs on human polymorphonuclear leukocytes (PMNL). The functional activity of neutrophilic granulocytes was assayed by measuring luminol-dependent chemiluminescence (CL) using luminometer LKB 1251. Rice starch and opsonized $E$. coli were used in testing phagocytosis by isolated granulocytes. The cells were incubated with antibiotics in subinhibitory and inhibitory concentrations with a special attention to their therapeutic levels. The tested antibiotics produced various effects on phagocyte $\mathbf{C L}$ regardless their chemical relationships. Those antibiotics which can penetrate into the phagocyte were especially effective. Lincomycin, ampicillin, gentamicin, chloramphenicol and rolitetracycline had no effect, clindamycin, oxacillin and polymyxin B increased $\mathrm{CL}$ in therapeutical concentrations; doxycycline, rifampicin, erythromycin, adriamycin and trimethoprim-sulphamethoxazole in therapheutical concentrations reduced CL activity of phagocytosing granulocytes. Clindamycin and trimethoprim-sulphamethoxazole potentiated CL activity in subtherapeutical concentrations.

Antimicrobial agents, immunomodulation, polymorphonuclear leukocytes, chemiluminescence

During the last 20 years, a growing interest has arisen in the study of interactions between antimicrobial agents and host defence systems. Since polymorphonuclear neutrophils (PMNL) act as the first line of defence against bacteria, functional alterations of these cells by antibiotics could explain, at least in part, some of the discrepancies observed between in vitro antibacterial activity and clinical efficacy ( $\mathrm{L}$ a b r o et al. 1986).

When PMNL interact with soluble and particulate stimuli, the cells respond with a burst in oxidative metabolism which generates chemically reactive molecules, e. g., superoxide anions $\left(\mathrm{O}_{2}\right)$ and hydrogen peroxide $\left(\mathrm{H}_{2} \mathrm{O}_{2}\right)$. This activation, which is an essential step in host defence against invading microorganisms, is accompanied by light emission or chemiluminescence by the cells (A 11 e n et al. 1972). The addition of luminol to a CL system has been shown to amplify the response and to simplify the measuring procedure (A $11 \mathrm{e} \mathrm{n}$ and $\mathrm{L}$ o o s e 1976).

The luminol-enhanced system obviates the need for working under dark-adapted conditions (D e Chat ele t and S hirle y 1982), permits the use of very few cells ( $\mathrm{S} \mathrm{t}$ e v e $\mathrm{n}$ et al. 1978) and can in fact be used to measure CL in samples of whole blood (Kato et al. 1981). For this reason, the luminol-enhanced CL has been used increasingly as a means of assessing granulocyte metabolic activity associated with microbidical events, for screening granulocytes for defects in oxidative metabolism, for studying the interaction and/or effect of pharmacological agents on granulocytes and for following disease activity in humans ( $D$ a $\mathrm{h} 1 \mathrm{~g} \mathrm{r}$ e $\mathrm{n}$ and L o c k 1988).

* Corespondence: Dr. J. Lokaj 
In this report we have investigated the effects of some commonly used antimicrobial agents on the production of CL from resting and stimulated PMNL.

Mateids and Mothod

\section{Antimicrobial Agents}

The following commercially available compounds were used: ampicillin (Pentrexyl, Bristol), oxacillin (Oxacilin, Spofa), polymyxin B (Aerosporin, Welloome), clindamycin (Klindamicinfosfat, Upjohn - Inex Hemofarm), lincomycin (Lincomycine hydrochloride, Medeexport), erythromycin (Erythrocin, Abbott), gentamicin (Gentamycin, Pharmachin), chloramphenicol (Chloramfenikol, Spofa), doxycycline (Vibramycin, Pfizer), rolitetracycline (Rolitetracyklin, Spofa), rifampicin (Rimactane, Ciba), adriamycin (Adriblastine, Farmitalia), trimethoprim-sulphamethoxazole (Septrin, Wellcome).

The antimicrobial agents were diluted in normal saline and adjusted to pH 7. 2. -7. 4.

Preparation of Polymorphorphonuclear Granulocytes

Heparinized peripheral blood obtained from healthy volunteers was first layered on Verografin (Spofa) - dextran (Pharmacia) gradient (density $1.080 \mathrm{~g} / \mathrm{ml}$ ). Blood was sedimented for one hour at $23^{\circ} \mathrm{C}$. Then the leukocyte - enriched plasma was layered on Lymphoprep gradient (density $1.077 \pm 0.001 \mathrm{~g} / \mathrm{ml}$, Nyegaard) and centrifuged for $30 \mathrm{~min}$ at $400 \mathrm{~g}$ at room temperature. Remaining erythrocytes in the supernatant were removed by an incubation with $0.87 \%$ ammonium chloride. Purified PMNL were rinsed twice in medium (MEM, USOL-Prague) and resuspended in medium at the final concentration of $1 \times 10^{6} \mathrm{PMNL} / \mathrm{ml}$. The cells were preincubated with different concentrations of antimicrobial agents at $37^{\circ} \mathrm{C}$ for $30 \mathrm{~min}$ and then immediately utilised in chemiluminescence assay.

PMNL viability after an incubation with the agents was determined by means of Trypan Blue dye test.

Opsonization of E. coli B

Prior to the use, $E$. coll B was opsonized with human plasma. The sediment of $5 \mathrm{ml}$ stationary culture (heat killed) of the strain was obtained by centrifugation and added to $3 \mathrm{ml}$ plasma. After an incubation in shaking water bath at $37^{\circ} \mathrm{C}$ for $30 \mathrm{~min}$, the bacteria were washed twice with MEM medium and finally suspended in $5 \mathrm{ml}$ of MEM medium. The density of opsonized $E$ coli $B$ was usually about $1.5 \times 10^{9} \mathrm{cells} / \mathrm{ml}$.

\section{Chemiluminescence Assay}

Automated luminometer set-up allowing a simultaneous and continuous measurement of up to 25 samples (LKB Wallac 1251 Luminometer connected to Apple II- microcomputer) was used.

Suspensions of reacents and PMNL (pretreated with antibiotics) were pipetted into $4 \mathrm{ml}$ polystyrene sample vials outside the luminometer. The activation of leukocytes commenced when the contents of the vials were warmed up to $37^{\circ} \mathrm{C}$ in the temperature controlled sample carousel of the instrument.

Cl emission was measured at $37^{\circ} \mathrm{C}$ for $60 \mathrm{~min}$ in a volume of 600 , $\mathrm{Ml}$ of medium including $100 \mathrm{\mu l}$ antibiotic (at a defined concentration), $100 \mathrm{al}$ PMNL $(1 \times 10 \% / \mathrm{ml}), 100 \mathrm{\mu l}$ luminol $(1 \times 10 \mathrm{M}$, Sigma), 100 ul opsonized $\mathrm{E}$. coli or amyllum oryzae (1\% suspension in saline, $10 \mathrm{mg} / \mathrm{ml}$ ) or medium (control).

The maximum CL emission in millivolts (mV) was plotted against each blood sample. The data determined in this way with antibiotic-pretreated cells were related to the corresponding value of the antibiotic-free control.

We took the abolute value of the control CL reaction as $100 \%$ and expressed the $\mathrm{CL}$ of antibiotic-pretreated cells relative percentages of this value.

\section{St a t is t i cs}

The result of each particular experiment is the mean of 10 measurements \pm SEM representing the response of 10 different donors.

The results of the experiments were evaluated by means of a two-factor analysis of variance 
where the two factors - i. a the effect of a stimulant and that of an antibiotic concentration were assessed both simultaneously and with regard to their interactions.

To assess the significance of the differences between antibiotic concentration levels a t-test was used where several groups were compared with each other on the basic of an increased critical value by applying the Bonferroni's inequality.

\section{Results}

13 antimicrobial agents tested under identical experimental conditions showed a stimulating or an immunosuppressive or no effect on the phagocytosis-associated CL.

Uniformly, the PMNL were preincubated with different concentrations (minimum, therapeutical, maximum) of the appropriate antibiotic for $30 \mathrm{~min}$ at $37^{\circ} \mathrm{C}$. Then the $\mathrm{CL}$ reaction was initiated by the addition of luminol and a stimulant to the reaction mixture. For every sample containing an antimicrobial agent there was a control sample containing only medium that was run in parallel.

The viability of PMNL after their incubation with the highest concentration of the antimicrobial agent under study was assessed by the trypan blue exclusion technique. No differences in the number of stained cells could be found between the samples containing an antimicrobial agent and those with control medium. Table 1 shows those substances (including the investigated concentrations) which did not influence the CL reaction after an incubation of the PMNL with subtherapeutical, therapeutical and supratherapeutical concentrations.

Table 1

Antibiotics without an effect on the CL of PMNL

Concentrations (ug/ml)

Antibiotic

subthera-

peutical

thera-

suprathera-

peutical

\begin{tabular}{llrr}
\hline Ampicillin & 0.5 & 8 & 64 \\
Linkomycin & 0.5 & 15 & 45 \\
Gentamicin & 1 & 10 & 50 \\
Chloramphenicol & 1 & 10 & 100 \\
Rolitetracyclin & 0.5 & 4 & 64 \\
\hline
\end{tabular}

The other antimicrobial agents exerted a positive or negative influence on the CL reaction of PMNL.

Clindamycin significantly increased light emission by stimulated PMNL at all tested concentrations (Fig. 1).

Oxacilin potentiated CL activity of PMNL stimulated with opsonized $E$. coli at concentrations, which are in the range of obtainable serum levels (Fig. 2).

Polymyxin B stimulated CL reaction at therapeutical and higher concentrations (Fig. 3).

Amicrobial agents like trimethoprim-sulphamethoxazole, rifampicin, adriamycin, doxycycline and erythromycin significantly reduced the CL response 


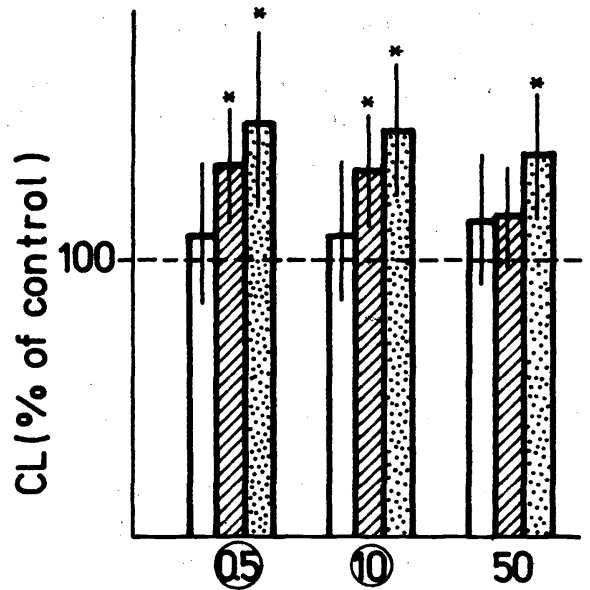

Fig.1. Effect of clindamycin on the $\mathrm{CL}$ response of PMNL

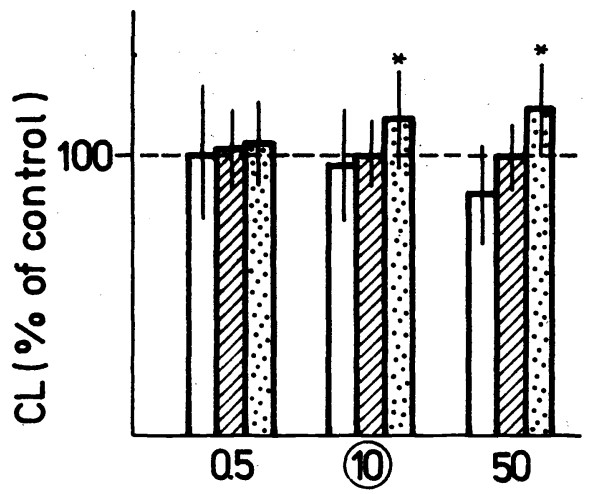

Fig.3. Effect of polymyxin $\mathrm{B}$ on the $\mathrm{CL}$ response of PMNL

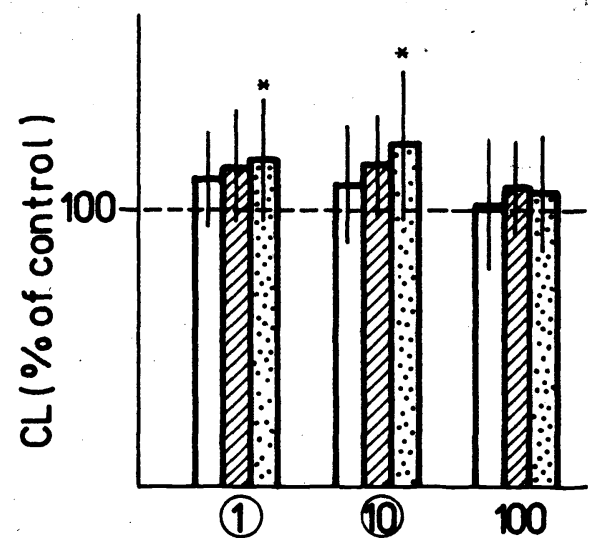

Fig. 2. Effect of oxacillin on the $\mathrm{CL}$ response of PMNL

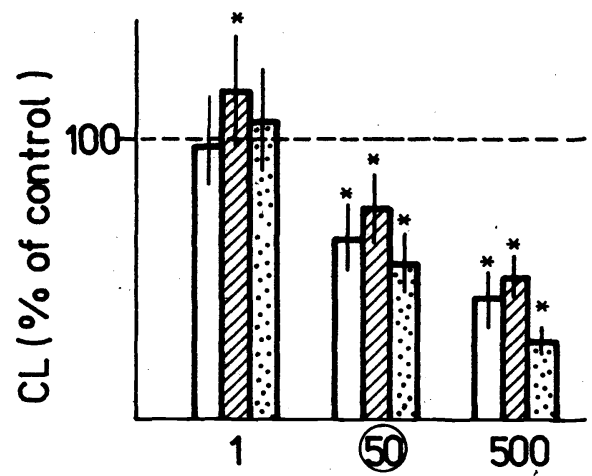

Fig.4. Effect of trimethoprim/sulphamethoxazole on the CLresponse of PMNL

Notes:

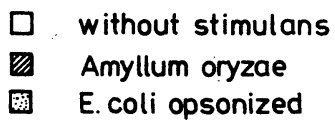
O therapeutic concentrations
* $p<0.05$

at therapeutical and maximum concentrations (Fig. 4, 5, 6, 7, 8). Trimethoprim-sulphamethoxazole at the subtherapeutical concentration stimulated the CL response of PMNL.

With most antibiotics we observed a transition from a mild immunomodulating effect with subtherapeutical concentrations to a markedly increasing suppression with therapeutical and supratherapeutical concentrations.

Antimicrobial agents produced different CL responses in relation to resting and stimulated phagocytes and in relation to the used stimulants (opsonized 
$E$. coli or amyllum oryzae). The tested antibiotics produced various effects on the phagocytosis - associated CL regardless their chemical relationships (doxycycline - rolitetracycline, clindamycin - linkomycin, oxacillin - ampicillin).

Some antimicrobial agents affected not only the maximum CL responses but they also inluenced the kinetics of CL. Doxycycline and adriamycin produced delayed responses of $\mathrm{CL}$ with higher concentrations (data not shown).

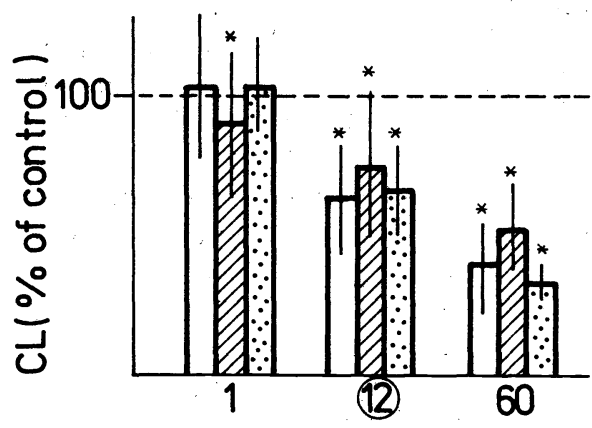

Fig.5. Effect of rifampicin on the $\mathrm{CL}$ response of PMNL

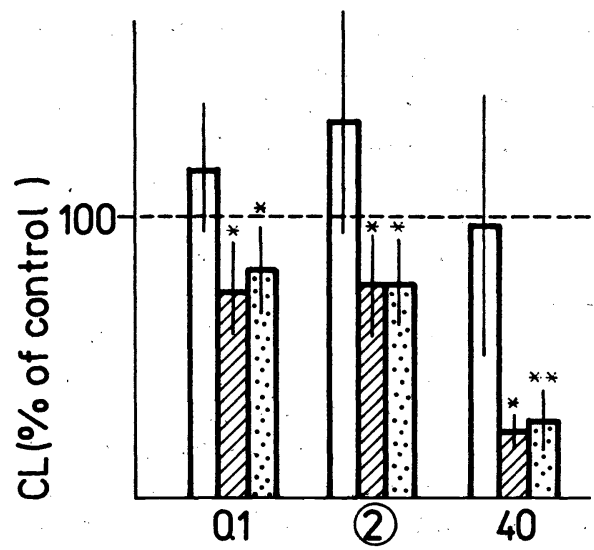

Fig.7. Effect of doxycycline on $\mathrm{CL}$ response of PMNL

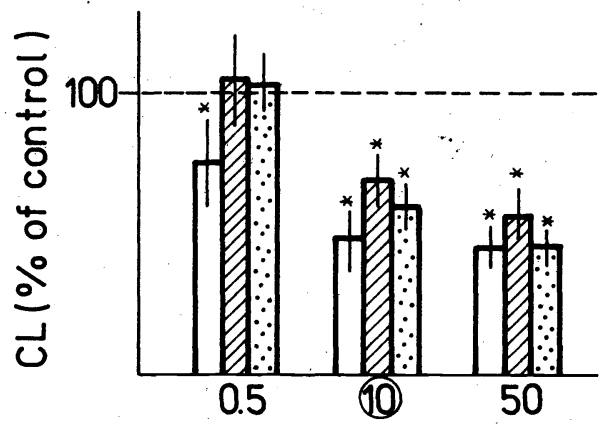

Fig.6. Effect of adriamycin on the $\mathrm{CL}$ response of PMNL

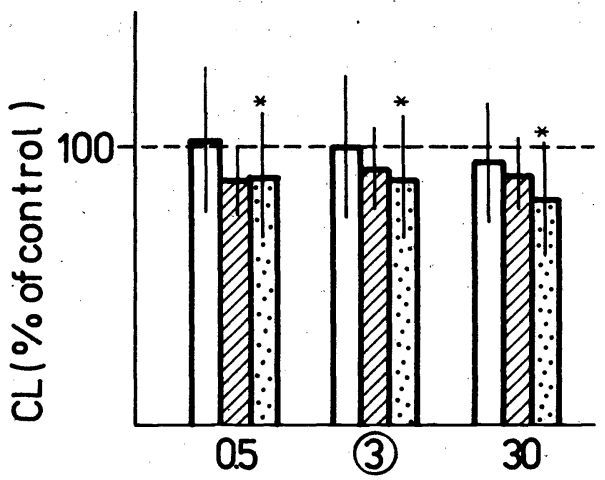

Fig. 8. Effect of erythromycin on the $\mathrm{CL}$ response of PMNL

O therapeutic concentrations

* $p<0.05$ 


\section{Discussion}

In the field of classical chemotherapy interest is focused mainly on the interaction of antibiotics and pathogens. In the past the influence of antimicrobial agents on the specific and unspecific host defence mechanisms was studied only sporadically, but during the past few years the interest in this special field has grown exponentially.

At this time it is recognized, that not only bacteria are affected by antibiotics, but it is also the host defence mechanisms that are influenced either direcly (in the absence of microorganisms) or indirectly (by changes in the structure or metabolic products of germs induced by subminimal inhibitory concentrations), in a positive or negative sense ( $G$ i 11 i s s e $n$ 1988).

We concentrated our studies on human PMNL, because PMNL compose a major portion of the peripheral leukocytes and represent the first line of defence of man and animals against invading microorganisms. PMN phagocytize, kill and eliminate bacteria, fungi, and other microorganisms. We studied the direct effect of widely used antibiotics of various classes on this important cell population. As a test model we used the measurement of the phagocytosis-associated CL. The luminol-enhanced CL assay has been use to study the metabolic activity of PMNL associated with microbicidal processes ( $\mathrm{H}$ o r a $\mathrm{n}$ et al. 1982). The technique is rapid and easy to perform, making it possible to run several samples in parallel in a short time. For this reason the technique has been found suitable for studying drug-induced effects on PMNL function (B r i he im and Dahlgren 1987).

There exist several reports on the effects of different antimicrobial agents on the CL from PMNL, but the results are difficult to interpret because of conflicting data.

Our results agree with most authors reporting very little effects of $\beta$-lactam antibiotics and aminoglycosides on the various functions of phagocytois (W e l c h et al. 1981; L i m be r t et al. 1982). In our experiments ampicillin and gentamicin did not produce any significant effects on CL. We found a modulation of the $C L$ reaction only for oxacillin, which stimulated $C L$ of PMNL at therapeutical concentrations.

Polymyxin B was found to inhibit phagocytosis in high concentrations ( D o wney and P is c a no 1965; B i cker and Fusche 1975) but no effect of therapeutic doses was detected ( $\mathrm{H} \mathrm{o} \mathrm{e} \mathrm{pri} \mathrm{ch}$ and $\mathrm{Mar}$ i in 1970). Enhanced intracellular killing (A d a m et al. 1971), a decrease (B ö rkste n et al. 1976) or no effect of this antibiotic on the phagocytosis-induced CL (D u n c k e r and $U 11 \mathrm{~m}$ a $\mathrm{n} \mathrm{n} \mathrm{1986)} \mathrm{have} \mathrm{also} \mathrm{been} \mathrm{reported.} \mathrm{In} \mathrm{our} \mathrm{experiment} \mathrm{polymyxin} \mathrm{B}$ has been shown to cause an enhancement of the CL from PMNL stimulated with opsonized $E$. coli. We recorded a marked stimulating effect for clindamycin. Clindamycin potentiated CL response from stimulated but not from resting $\mathrm{PMNL}$ at all tested concentrations.

Clindamycin is an antibiotic which enters the cells by means of an active membrane transport system. The intracellular accumulation of this drug is 40-50 times the external concentration. Clindamycin remains inside the cell as long as extracellular fluid and tissue levels are maintained (K1 e m p n e r and S t y r t 1981; H a nd et al. 1983). The results with clindamycin are conflicting. The CL from PMNL isolated from persons undergoing a treatment with clindamycin was found to be inhibited ( $\mathrm{F} \mathrm{a} \mathrm{de} \mathrm{n}$ et al. 1983), whereas 
a treatment of PMNL with clindamycin in vitro resulted in an enhancement of the CL (Oleske et al. 1983; Scevola et al. 1986), and the CL generated in whole blood was found to be unaffected by a treatment with clindamycin (S c e v o la et al. 1986).

Tetracycline derivatives exert an overall influence on many granulocyte activities, reducing adherence, migration, quantitative phagocytosis and chemiluminescence. This influence is dose-dependent, and also depends on the particular tetracyclines used ( $\mathrm{G} \mathrm{n}$ a r pe and B e $1 \mathrm{~s} \mathrm{~h}$ e i m 1985).

As clearly demonstrated by our results there is a difference between the immunomodulating effects of doxycycline and rolitetracycline. The differences observed are most likely due to the lipid solubilities of the drugs which allow doxycycline, a highly lipid-soluble compound, to readily penetrate cell membranes. As tetracyclines are potent chelating agents and as granulocyte membrane deformability, necessary for migration and phagocytosis, is dependent on divalent cations $\left(\mathrm{Ca}^{2+}\right.$ and $\left.\mathrm{Mg}^{2+}\right)$, which are also vital for the oxidative burst, it seems likely that the accumulated intracellular tetracycline prevents free movement of these cations across the PMNL membrane ( $\mathrm{G} \mathrm{n}$ a r pe and $\mathrm{B}$ e $1 \mathrm{sh}$ e i m 1985). Our results with doxycycline agree with other authors ( $\mathrm{We} l \mathrm{ch}$ et al. 1981; S i e ge 1 and $R$ e m in g t o n 1982; L i m bert et al. 1982; G l e t t e etal. 1984; G narpe and Bels heim 1985; Duncker and U $11 \mathrm{mann}$ 1986).

Rifampicin has been shown to accumulate and retain its bactericidal activity in granulocytes ( $\mathrm{S}$ o $1 \mathrm{~b}$ e r g and $\mathrm{He} 11 \mathrm{u} \mathrm{m} \mathrm{1978;} \mathrm{M}$ a n d e 11 1983; W o s $\mathrm{b} \mathrm{e} \mathrm{c} \mathrm{k} \mathrm{et} \mathrm{al.} \mathrm{1984).} \mathrm{Intracellular} \mathrm{accumulation} \mathrm{of} \mathrm{rifampicin} \mathrm{inside} \mathrm{PMNL}$ could be hazardous to their normal function, because the antibiotic posseses immunosuppressive functions ( $\mathrm{P}$ a u n e s c $1970 ; \mathrm{G}$ r a s i and $\mathrm{P}$ os s i 1972; B a s s i et al. 1973; $\mathrm{D}$ a j a $\mathrm{n}$ i et al. 1973). The inhibition of CL with rifampicin in our experiments was also recorded by $\mathrm{H} \ddot{\mathrm{g}} \mathrm{er}$ et al. (1982) and by Si e ge 1 and Re ming to $n$ (1982).

$\mathrm{S}$ i e g e l and $\mathrm{Re} \mathrm{m}$ i $\mathrm{g}$ t o $\mathrm{n}$ (1982) presumed that an absorption of light might be mainly responsible for the effect of rifampicin as the substance is orange and the addition during a CL assay resulted in an immediate drop of CL impulse rate.

Contrary to this, trimethoprim and sulphamethoxazole, both individually and in combination, seem to interfere with processes of the respiratory burst as the effects are not seen in a cell-free system (D u n c k e r and U $11 \mathrm{~m} \mathrm{a} \mathrm{n} \mathrm{n} \mathrm{1986).}$

Trimethoprim-Sulphamethoxazole has been found to cause an inhibition (W e l c h et al. 1981; S i e ge 1 and $R$ e $\mathrm{m}$ in g t o n 1982; D u n c ker and U $11 \mathrm{~m}$ a n n 1986) as well as an enhancement (O l e s k e et. al. 1983). In our experiments trimethoprim-sulphamethoxazole showed a stimulating effect on the $\mathrm{CL}$ response at the subtherapeutical concentration and a significantly inhibitory effect at the therapeutical and higher concentrations.

A significant decrease in the metabolic burst of resting and stimulated cells was demonstrated in our study with adriamycin. Y a n a i and Q u i e (1981) state that one of the prerequisites for $\mathrm{CL}$ is surface activation. Adriamycin cytotoxicity is localized to the cytoskeleton and to the cell membrane to a significant degree (Athlin et al. 1987). Whether the abnormalities in PMNL metabolic functions were due to a direct effect on the cell membrane, or to indirect effects through superoxide radical generation with a subsequent damage to 
the cell membrane by peroxidation of membrane lipids is unknown ( $\mathrm{P} \mathrm{i} \mathrm{c} \mathrm{k} \mathrm{e} \mathrm{-}$ ri in $\mathrm{g}$ et al. 1982).

These results reveal that antibiotic effects on phagocytic activity can neither be attributed to chemically related drugs nor to groups of comparable modes of action. This kind of antibiotic effect might, therefore, be explained by the particular activities of single drugs.

We have found that antibiotics which can easily penetrate into the phagocyte were especially effective (clindamycin, doxycycline, trimethoprim-sulphamethoxazole, erythromycin, rifampicin) but caution should be exercised before generalizing this fact. For instance, oxacilin and polymyxin B are antibiotics with poor lipid solubility, entering the phagocyte rather poorly, and we found significantly stimulating effect with these antibiotics, On the other hand, lincomycin is taken up actively by human PMNL, but in our experiments the CL reaction was found to be unaffected by the treatment with lincomycin.

In summary, when choosing antimicrobial agents for therapy it is important to consider not only the sensitivity of the bacteria but also any possible effects on the host-defence system of which the PMNL is an important part.

\section{Acknowledgements}

We wish to thank MUDr. J. Vácha, DrSc. for the statistical analyses and V. Seidlová and L. Súchopová for technical assistance.

Vliv subinhibienich a inhibienich koncentraci antimikrobiálních látek na chemiluminiscenci fagocytujících granulocytů

Úkolem studie bylo zjistit účinek běžně použivaných antibakteriálních léků na lidské granulocyty $\mathrm{z}$ periferní krve. Funkční aktivita neutrofilních granulocytů byla vyšetřována testem luminol-dependentní chemiluminiscence (CL) na luminometru LKB 1251. Pro fagocytózu izolovaných granulocytủ byl použit rýžový škrob a opsonizované $E$. coli. Buňky byly inkubované s antibiotiky v subinhibičních a inhibičních koncentracích, se zvláštním zřetelem $\mathbf{k}$ jejich běžným terapeutickým hladinám. Vyšetřovaná antibiotika měla, bez ohledu na chemickou príbuznost, rozdílný vliv na CL fagocytů. Zvlášt účinná byla ta antibiotika, která jsou schopna do fagocytů pronikat. Antibiotika linkomycin, ampicilin, gentamicin, chloramfenikol a rolitetracyklin neovlivnovala CL odpověd granulocytú. Klindamycin, oxacilin a polymyxin B v terapeutických koncentracích CL reakci zvyšovaly, zatímco doxycyklin, rifampicin, erytromycin, adriamycin a trimethoprim-sulfamethoxazol $\mathrm{v}$ terapeutických koncentracích ji snižovaly. Klindamycin a trimethoprim-sulfamethoxazol $\mathrm{v}$ subterapeutických koncentracích $\mathrm{CL}$ aktivitu zvyšovaly.

\section{Действие субингибирующих концентраций антимикробильных веществ на хемилюминисцевцию гранулоцитов человека}

Целью работы являлось изучение действия широко применяемых антибактериальных лекарств на гранулоциты человека из переферической крови. Функциональная активность нейтрофильных гранулоцитов 
исследовалась при помощи теста люминол-депендентной хемилюминисценции (ХЛ) на люминометре ЛКБ 1251. С целью фагоцитоза изолированных гранулоцитов применялся рисовый крахмал и опсонизированные $E$. coli. Клетки инкубировались с антибиотиками в субингибирующих и ингибирующих концентрациях с учетом их применяемого терапевтического уровня. Исследуемые антибиотики имели не смотря на их химическое средство, различное влияние на ХЛ фагоцитов. Особенно действенными оказались те антибиотики, которые были способными проникать в фагоциты. Антибиотики линкомицин, ампициллин, гентамицин, хлорамфеникол и ролитетрациклин не оказывали влияния на ХЛ ответ фагоцитов. Клиндамицин, оксациллин и полимиксин В при терапевтических концентрациях реакцию ХЛ повышали, в то время как доксициклин, рифампицин, эритромицин, адриамицин и триметоприм-сульфаметоксазол при терапевтических концентрациях ее снижали. Клиндамицин и триметоприм-сульфаметоксазол при субтерапевтических концентрациях активность ХЛ повышали.

\section{References}

ADAM, D. - PHILLIP, P. - BELOHRADSKÝ, B. H.: Studies on the influence of host defence mechanisms on the antimicrobial effect of chemotherapeutic agents. Effect of antibiotics on phagocytosis of mouse-peritoneal-macrophages in vitro. Arztl Forsch., 25, 1971: 181-184.

ALLEN, R. C. - LOOSE, L. D.: Phagocytic activation of a luminol-depent chemiluminescence in rabbit alveolar and peritoneal macrophages. Biochem. Biophys. Res. Commun., 69, 1976: 245-252.

ALLEN, R. C. - STJERNHOLM, R C. - STEEL, R. H.: Evidence for the generation of electronic excitation states in human polymorphonuclear leukocytes and its partipation in bactericidal activity. Biochem. Biophys. Res. Commun., 47. 1972: 679-684.

ATHLIN, L. - DEMOLLÖF, L. - NORBERG, B. O.: Phagocytosis of yeast cells by monocytes. effects of fluorouracil, doxorubicin and mitomycin. European Journal of Surgical., 13, 1987: $51-55$.

BASSI, L. L. - Di BERARDINO, L. - ARIOLI, V. - SILVESTRI, L. G. - LIGNIERE, E. L. C.: Conditions for immunosuppresion by rifampicin. J. Infect: Dis., 128, 1973: 734-744.

BICKER, V. - FUHSE, P.: Carcinostatic action of 2-cyana-ziridines against a sarcoma in rats. Exp. Path., 10, 1975: 279-284.

BJÖRKSTEN, B. - RAY, C. - QUITE, R. G.: Inhibition of human neutrophil chemotaxis and chemiluminescence by amphotericin B. Infect. Immun., 14, 1976: 315-317.

BRIHEIM, G. - DAHLGREN, C.: Influence of antibiotics on formylmethionylleucyl-phenylalanine-induced leukocyte chemiluminescence. Antimicrob. Agents Chemother., 31, 1987: 763-767.

DAHLGREN, C. - LOCK, R.: The limitation of the human neutrophil chemiluminescence response by extracellular peroxidase is stimulus dependent: effect of added horse radish peroxidase on the response induced by both soluble and particulate stimuli. J. Clin, Lab. Immunol. 26, 1988: 49-53

DAJANI, B. - KASIK, J. - THOMPSON, J. S.: Effect of rifampin on the immune response in guinea pigs. Antimicrob. Agents Chemother., $3,1973: 451-455$.

DE CHATELET, L. R. - SHIRLEY P.- S.: Evaluation of chronic granulomatous disease by chemiluminescence assay of microliter quantilies of whole blood. Clin. Chem., 27, 1982: 1739-1741.

DOWNEY, R. J. - PISCANO, J. C.: Some effect of antimicrobial compounds on phagocytosis in vitro. J. Reticuloendothel. Soc., 2, 1965: 75-88.

DUNKER, D. - ULLMANN, V.: Influence of various antimicrobial agents on the chemiluminescence of phagocytosing human granulocytes. Chemotherapy, 32, 1986: 18-24.

FADEN, H. - HONG, J. J. - OGRA, P. L.: In vivo effects of clindamycin on neutrophil function - a preliminary report. J. Antimicrob. Chemother., 12 (Suppl. C), 1983: 29-34. 
GRASSI, G. - POZZI, E.: Effect of rifampin on delayed hypersesitivity reactions. J. Infect. Disc., 5, 1972: 542-544.

GILLISSEN, G.: Side effects of antibiotics on immune response parameters and their possible implications in antimicrobial chemotherapy. Zbl. Bakt. Hyg., A 270, 1988: 171-199.

GLETTE, J. - SANDBERG, S. - HOPEN, G. - SOLBEERG, C. O.: Influence of tetracyclines on human polymorphonuclear leukocyte functions. Antimicrob. Agents Chemother., 25, 1984: 354-357.

GNARPE, H. - BELSHEIM, J.: Interaction of antibiotics with granulocytes and lymphocytes. Zbl. Bakt., 13 (Suppl.), 1985: 123-141.

HAND, W. L. - NEVA, L. - KING-THOMPSON, N. L. - STEINBERG, T. H.: Interaction of antibiotics and phagocytes. J. Antimicrob. Chemotherapy, 12 (Suppl. C), 1983: 1-11.

HOEPRICH. P. D. - MARTIN, C. H.: Effect of tetracykline, polymyxin B and rifampicin on phagocytosis. Clin. Pharmacol. Ther., 11, 1970: 418-422.

HORAN, T. D. - ENGLISCH, D. - MC PHERSON, T. A.: Association of neutrophil chemiluminescence with microbicidal activity. Clin. Immunol. Immunopathol., 22, 1982: 259-269.

HÖGER, P. H. - VOSBECK, K. - SEGER, R - HITIG, W. H.: Uptake, intracellular activity, and influence of rifampin on normal function of polymorphonuclear leukocytes. Antimicrob. Agents Chemother., 28, 1985: 667-674.

KAISK, J. E. - MONICK, M.: Comparison of antibacterial and antiimmune effects of certain rifamycins. Antimicrob. Agents Chemother., 19, 1981: 134-138.

KATO, T. - WOKALEK, H. - SCHÖPF, E. - EGGERT, H. - ERNST, M. - RIETSCHEL, E. FISCHER, H.: Measurement of chemiluminescence in freshly drawn human blood. Clin. Wochenschr., 59, 1981: 203-211.

KLEMPNER, M. A. - STYRT, B.: Clindamycin uptake by human neutrophils. Journal of Infections, 114, 1981: 472-479.

LABRO, M. T. - AMIT, N. - BABINCHERAYE, C. - HAKIM, J.: Synergy between RU 28965 (Roxthromycin) and human neutrophils for bactericidal activity in vitro. Antimicrob. Agents Chemother., 30, 1986: 137-142.

LIMBERT, M. - SEIBERT, G. - SCHRINNER, E.: The influence of antibiotics on the phagocytosis-associated chemiluminescence of guinea pig polymophonuclear neutrophils. In: The influence of antibiotics on the host-parasite relationship. H. -V. EICHENBERG, H. HAHN, W. OPFERKUCH (Eds.) Springer-Verlag: New York, 1982: 74-86.

MANDELL, G. L.: The antimicrobial activity of rifampin: emphasis on the relation to phagocytes. Rev. Infect. Dis., 5 (Suppl. 3), 1983: 463-467.

OLESKE, J. M. - CRUZ, A - AHDIEH, H. - SORVINO, D. - BRAICO, J. - COOPER, R. -

SINGH, R. - LIN, R - MINNEFOR, A.: Effects of antibiotics on polymorphonuclear leukocyte chemiluminescence and chemotaxis. J. Antimicrob. Chemother., 12 (Suppl. C), 1983: 33-38.

PAUNESCU, E.: In vivo and in vitro suppression of humoral and cellular immunological response by rifampicin. Nature, 228, 1970: 1188-1190.

PICKERING, L. K. - ERICSSON, C. D. - KOHL. S.: Effect of chemotherapeutic agents on metabolic and bactericidal activity of polymorphonuclear leukocytes. Cancer, 42, 1978: 1741-1746 .

SCEVOLA, D. - CONCIAE. - TINELLI. M. - BENZI, R - MONZILLO, V. - CREMONESI, G.: Chemiluminescence, phagocytosis, chemotaxis and killing activity of human leukocytes exposed to clindamycin. Microbiologica, 9, 1986: 209-214.

SIEGEL, J. P. - REMINGTON, J. S.: Effect of antimicrobial agents on chemiluminescence of human polymorphonuclear leukocytes in response to phagocytosis. J. Antimicrob. Chemother., 10, 1982: 505-515.

SOLBERG, C. O. - HELLUM, K. B.: Protection of phagocyted bacteria against antimicrobial agents. Scand. J. Infect. Dis., 14 (Suppl.), 1978: 246-250.

STEVENS, P. - WINSTON, D. J. - DYKE, K. In vitro evaluation of opsonic and cellular granulocyte function by luminol-dependent chemiluminescence. Utility in patients with severe neutrophenia and cellular deficiency states. Infect. Immun., 22, 1978: 41-51.

VOSBECK, K - JAMES, P. R. - ZIMMERMANN, W.: Antibiotic action on phagocytosed bacteria measured by a new method for determining viable bacteria. Antimicrob. Agents Chemother., 25, 1984: 735-741.

WELCH, W. D. - DAVS, D. - THRUPP, L. D.: Effect of antimicrobial agents on human polymorphonuclear leukocyte microbicidal function. Antimicrob. Agents Chemother., 20, 1981: 15-20.

YANAI, M. - QUIE, R G.: Chemiluminescence by polymorphonuclear leukocytes adhering to surfaces. Infect. Immun., 32, 1981, 1181. 